\title{
IMPLEMENTATION AND READINESS OF ONLINE LEARNING PEDAGOGY: A TRANSITION TO COVID 19 PANDEMIC
}

\author{
Leovgildo Lito D. Mallillin', \\ Lorna Casoco Mendoza ${ }^{2}$, \\ Jocelyn B. Mallillin', \\ Rosina C. Felix ${ }^{4}$, \\ Imelda C. Lipayon ${ }^{5 i}$ \\ ${ }^{1} \mathrm{PhD}$, Gulf College, \\ Sultanate of Oman \\ ${ }^{2} \mathrm{LPT}$, Head Teacher V, \\ Quezon City Science High School, \\ Quezon City, Philippines \\ ${ }^{3} \mathrm{LPT}$, Master Teacher 1, \\ San Bartolome High School, \\ Novaliches, Quezon City, Philippines \\ ${ }^{4} \mathrm{LPT}$, Teacher 11, Bacabac Elementary School, \\ Camiling, Tarlac, Philippines \\ ${ }_{5}^{5} \mathrm{PhD}$, Master Teacher 1, Novaliches High School, \\ Novaliches, Quezon City, Philippines
}

\begin{abstract}
:
Online learning education pedagogy is the trend at present in the educational system due to Covid 19 pandemic crises. It explores the pedagogical design in the academic competency of student development in various digital learning literacy on technology collaborative enhance learning. The study aims to identify the different transition of Covid 19 pandemic in the implementation and readiness of online learning for both teachers and students in terms of access to digital work, availability of technology, adequacy of technology, access to effective online learning platform, access to link of internet, and school practices to online teaching. Descriptive quantitative method is employed in the study because it provides a systematic and accuracy that describes the phenomenon of the current study. Purposive sampling technique is utilised in the study because it is subjective, selective, and judgmental sampling. The study compromised one hundred fifty (150) respondents. Results show that online learning fits the different pedagogy of learning tools, resources, course materials in the access to digital work, transform student responsibility and learning experience to new opportunity of learning
\end{abstract}

iCorrespondence: email loviedsubright_0722@yahoo.com.ph, lorna.mendoza008@deped.gov.ph, jomallillin@yahoo.com, rosina.felix002@deped.gov.ph, doc.imeldalipayon@yahoo.com 
and empowers student on technology to be more creative and connected in their online learning classes and activities in the availability of technology, accessibility to online learning process that enable to study or teach anywhere and anytime through internet connection as advantage for student and allow for a customise learning experience flexibility to study at their level and ability to improve learning dynamic in adequacy of technology, enhance professional skill in online learning and teaching through skill, attitude, and knowledge in a competitive world of e-learning tailored with the global demand of education due to Covid 19 pandemic in access to effective online learning platform, provide access to internet that use for online teaching to communicate, manage, create, gather, access, and distribute information for student learning in access to link of internet, and open for adjustment and constructive feedback in a novice teaching online and innovation to technology that will be helpful for student learning school practice online teaching.

Keywords: online learning pedagogy, implementation and readiness, access to digital work, availability of technology, adequacy of technology, online learning platform, access to link of internet, school practices to online teaching

\section{Introduction}

Online learning education pedagogy is the trend at present in the educational system due to Covid 19 pandemic crises. This is implemented in the Department of Education (DepEd), Commission on Higher Education (CHED), and other educational institutions to have a smooth flow of learning among student. This is inevitable circumstance where educational sectors need to address. The focus of the situation in the learning process of student as the center of knowledge enhancement through transition of Covid 19 pandemic greatly affects the adjustment of the learners. Student-centred learning pedagogy is different and sensitive from the setting of learning classroom to online setting of learning. Techniques and strategies are different process in learning, flow, and style. It explains how pedagogy of learning in implementation, readiness, and ethics in online environment and in establishing context learning. It provides learning perspective which highlights techniques in teaching instruction and behavior in the modules, subjects, and course designs in online learning. This can promote better learning to student in online teaching (Robinson, Al-Freih, \& Kilgore, 2020). On the other hand, due to the trend of technology online learning can be possible in different educational institutions. Different tools are introduced on the quality of teaching and collaborative learning. It explores the pedagogical design in the academic competency of student development in various digital learning literacy on technology collaborative enhance learning. It explores the different domains of learning transition due to Covid 19 pandemic. Mallillin, (2020) examined the various domain of learning in the academic performance of student in their cognitive, affective and psychomotor skills. In addition, online learning process provides development of different literacy on digital technology, 
concept and critical thinking. The significance of the new technology in online learning provides self-regulation in the digital literacy integration for both lecturers and students since learning is a two way process to cope with the learning outcome through adaption of design pedagogy and innovation (Blau, Shamir-Inbal, \&Avdiel, 2020).

Furthermore, Mallillin, Carag, Mallillin, \& Laurel (2020) stressed in their study on integration of knowledge through online classes in the learning enhancement of student influenced the module tutors in the teaching technology on their professional belief and knowledge which is centered to learning enhancement through online pedagogy. The authors identified the different issues in online learning process. It revealed in their studies that most of the problems encountered by students in their online learning classes were internet connection and devices which affect their academic performance especially those students who were adjusting from traditional classroom setting to online learning setting. They have difficulty in the adjustment of their learning habits. Hence, lecturers face various challenges in the online classes on how to handle the access to quality of education and professional development through technology utilisation for effective teaching. The implementation and design of the online learning is supported by the theory of learning on social constructivism that contributes to the framework of the study, (Powell \& Bodur, 2019). Therefore, implementation of online classes typically describes the predictive analysis learning. It is where the lecturers or teachers use and perceive the resources during the process of online learning. It empowers lecturers and teachers to evaluate and provide necessary direction to student during their online learning as transition to Covid 19 pandemic. The principle and pedagogy of technology provides an impact to the intervention, teaching, practice, and strategy in online learning support among student (Herodotou, Rienties, Boroowa, Zdrahal, \& Hlosta, 2019). Traditionally, implementation of online classes during Covid 19 pandemic adequately positions to teach and provides opportunity to student the learning process of technology as part of their curriculum to their module, practice, and intervention skills. The demand is based on the knowledge of teacher and belief. It is an online integration and interaction simulation toward advance technology among the learners (Putney, et. al., 2019).

Moreover, readiness to online learning pedagogy is provided for access to student and support during Covid 19 pandemic which is possible for learning process. It employs online learning strategies and techniques in a massive teaching. It predicts the assessment task for student performance especially on the model of teaching aspect in online process pedagogy. Additionally, it provides a sequence pattern to be used in online learning and behavior of student related to their performance in online setting learning (Malekian, Bailey, \& Kennedy, 2020, March). It also observes the readiness of student in their online learning pedagogy and process through dimension and confidence ability through different competencies on communication, technical, attribute, and time management online. It measures the readiness online which develops by the different educational institutions as response to student need during online classes. It is the instrument and factor that examines during the process of online in the transition process of Covid 19 pandemic. It measures the variance and analysis of the confidence and readiness of 
student. It attributes the different competencies in online learning (Martin, Stamper, \& Flowers, 2020). Subsequently, online learning pedagogy is mainstreamed by the different educational institutions temporarily because of Covid 19 pandemic to assist and help student in the continuation of their education. Lecturers are willing to teach and serve student online. The readiness of lecturers in online teaching explores their vulnerability in their profession because of their adjustment to technology from classroom setting to online lecture setting. This is another challenged for the lecturers in the different educational institutions (Cutri, \& Mena, 2020).

Furthermore, the transition of online learning pedagogy supports the different educational institutions in making decision to implement and to develop effective response to the learning process during the period of Covid 19 pandemic. It provides necessary precautionary measure and social distancing on both the lecturers and students. It is an effective technique and strategy to safeguard opportunity in online learning pedagogy. It provides educational leader to organise a system in the continuation of education alternative plan and modality which is necessary during this pandemic crisis. It offers framework and area to be covered during the process of online learning and teaching plan. It emerges the response and need of the different educational institutions not only in the country but throughout the universe. It provides salient need for the educational plan that needs to be addressed. It designates the challenges face by various educational institutions in online process and pedagogy of alternative learning modality (Reimers, \& Schleicher, 2020). Despite Covid19 pandemic education still continues through online process as a form of distance virtual learning. The different technologies are utilised in online learning like radio, TV live stream lesson, online portal, Microsoft team, Zoom, Google meet, and other alternative modality of learning. The system utilises online learning pedagogy that confirms the experiences of teachers in teaching process to reach students (Chen, Qian, \& Wen 2020). On the other hand, online learning transition replicates the traditional process of teaching into online process. However, this transition provides design and opportunity adequate for instruction and struggle in online learning process for lecturers and teachers in a synchronous setting alternative pedagogy and modality (Henriksen, Creely, \& Henderson, 2020).

\section{Research Questions}

1. What is the transition of Covid 19 pandemic in the implementation and readiness of online learning through:

a. Student:

1. access to digital work,

2. availability of technology,

3. adequacy of technology,

b. Teacher:

1. access to effective online learning platform,

2. access to link of internet, 
3. school practices to online teaching.

2. Is there a significant relationship between students and teachers in the transition of Covid 19 pandemic in the implementation and readiness of online learning among the respondents?

\subsection{Hypothesis}

There is no significant relationship between students and teachers in the transition of Covid 19 pandemic in the implementation and readiness of online learning among the respondents.

\section{Research Method}

Descriptive quantitative method is employed in the study because it provides a systematic and accuracy that describes the phenomenon of the current study. It answers how, where, when, and what the question is all about. It provides a research design for a variety of method in different variability and measurement of the study on the different transition of Covid 19 pandemic in the implementation and readiness of online learning for both students and teachers. It determines the competency of both students and teachers in online classes and teaching as to accessibility on digital work, availability of technology, adequacy of technology, accessibility to effective online learning platform, link of internet, and school practices to online teaching (Santika, 2019).

\subsection{Sampling Technique}

A non-probability sampling technique is used in the study which is purposive sampling and is based on the objectives and criteria used in getting the population of the study. It is convenience sampling in finding the target of the study because it is subjective, selective, and judgmental sampling. It examines the population of the entire subject under study. It is a technique sample to be used and to review the experience and event particularly in online learning pedagogy of population and group. It reviews and strengthens the various approaches in obtaining samples that provides evidence and viability of the target study. It is a subset sampling convenience for the subject chosen respondents. It relies on assumption base probable sampling. It argues the method appropriate for the observational research and it is a trade-off base design representative in obtaining a sufficient powerful sample size of the study (Klar, \& Leeper, 2019).

\subsection{Respondent of the Study}

The subjects of the study are the License Professional Teacher (LPT) who have experienced in online teaching. They belong to private and public educational institutions. Respondents are eligible in online teaching process to motivate students in the distance learning virtual lesson. The study compromised one hundred fifty (150) respondents (Febliza, \& Okatariani, 2020). 


\subsection{Research Instruments}

\section{A. Access to digital work}

4.20-5.00 Highly Observed

3.40-4.19 Observed

2.60-3.39 Neutral

1.80-2.59 Not Observed

1.00-1.79 Not Observed at All access to digital work is extremely satisfied access to digital work is very satisfied access to digital work is moderately satisfied access to digital work is slightly satisfied access to digital work is not satisfied at all

\section{B. Availability of technology}

4.20-5.00 Highly Observed

3.40-4.19 Observed

2.60-3.39 Neutral

1.80-2.59 Not Observed

1.00-1.79 Not Observed at All availability of technology is extremely satisfied availability of technology is very satisfied availability of technology is moderately satisfied availability of technology is slightly satisfied availability of technology is not satisfied at all

\section{Adequacy of technology}

\begin{tabular}{|c|c|c|}
\hline $4.20-5.00$ & Highly Observed & adequacy of technology is extremely satisfied \\
\hline $.40-4.19$ & Observed & adequacy of technology is very satisfied \\
\hline $.60-3.39$ & Neutral & adequacy of technology is moderately satisfied \\
\hline $80-2.59$ & Not Observed & adequacy of technology is slightly satisfied \\
\hline $0-1.79$ & Not Observed at All & adequacy of technology is not satisfied at all \\
\hline
\end{tabular}

D. Access to effective online learning platform

\begin{tabular}{|c|c|c|}
\hline $4.20-5.00$ & Highly Observed & effective online learning is extremely satisfied \\
\hline $3.40-4.19$ & Observed & effective online learning is very satisfied \\
\hline $.60-3.39$ & Neutral & effective online learning is moderately satisfied \\
\hline 80-2.59 & Not Observed & effective online learning is slightly satisfied \\
\hline $00-1.79$ & Not Observed at All & effective online learning is not satisfied at all \\
\hline
\end{tabular}

\section{E. Access to link of internet}

$\begin{array}{lll}\text { 4.20-5.00 } & \text { Highly Observed } & \text { access link to internet is extremely satisfied } \\ \text { 3.40-4.19 } & \text { Observed } & \text { access link to internet is very satisfied } \\ 2.60-3.39 & \text { Neutral } & \text { access link to internet is moderately satisfied } \\ 1.80-2.59 & \text { Not Observed } & \text { access link to internet is slightly satisfied } \\ 1.00-1.79 & \text { Not Observed at All } & \text { access link to internet is not satisfied at all }\end{array}$

\section{F. School practices to online teaching}
4.20-5.00
Highly Observed
online teaching school practices is extremely satisfied
$3.40-4.19$
Observed
2.60-3.39
Neutral
$1.80-2.59$
Not Observed
online teaching school practices is very satisfied
$1.00-1.79$
Not Observed at All online teaching school practices is moderately satisfied online teaching school practices is slightly satisfied online teaching school practices is not satisfied at all 


\section{Results}

Table 1: Implementation and readiness on the access to digital work

\begin{tabular}{|c|c|c|c|}
\hline Indicators & $\mathbf{W M}$ & Interpretation & Ranking \\
\hline $\begin{array}{l}\text { Align better with student technology used which is } \\
\text { reliable to digital devices in online learning process. }\end{array}$ & 2.79 & $\mathrm{~N}$ & 5 \\
\hline $\begin{array}{l}\text { Optimise course preparation, lesson planning, grading } \\
\text { of students, and understand the effort in individual } \\
\text { needs of learning and engagement. }\end{array}$ & 2.89 & $\mathrm{~N}$ & 2 \\
\hline $\begin{array}{l}\text { 3. Access student level insight into learning needs among } \\
\text { educational institution relying on time data from } \\
\text { program analysis dashboard to equip teachers for } \\
\text { understanding the needs of students. }\end{array}$ & 2.87 & $\mathrm{~N}$ & 3.5 \\
\hline $\begin{array}{l}\text { 4. Provide e-learning to fit the different pedagogy of } \\
\text { learning tools, resources, course materials to boost } \\
\text { the impact of online learning process. }\end{array}$ & 2.99 & $\mathrm{~N}$ & 1 \\
\hline $\begin{array}{l}\text { 5. Provide student access to online education content } \\
\text { needed in an affordable increase of discipline and } \\
\text { challenges in their alternative learning. }\end{array}$ & 2.87 & $\mathrm{~N}$ & 3.5 \\
\hline Average Weighted Mean & 2.88 & $\mathrm{~N}$ & \\
\hline Standard Deviation & 0.055 & & \\
\hline
\end{tabular}

Table 1 presents the weighted mean and the corresponding interpretation on student access to digital work. It is noted that rank 1 is "Provide e-learning to fit the different pedagogy of learning tools, resources, course materials to boost the impact of online learning process" (WM=2.99) Neutral, rank 2 is "Optimise course preparation, lesson planning, grading of students, and understand the effort in individual needs of learning and engagement" (WM=2.89) Neutral, rank 3 is shared by the two indicators which are "Access student level insight into learning needs among educational institution relying on time data from program analysis dashboard to equip teachers for understanding the needs of students" and "Provide student access to online education content needed in an affordable increase of discipline and challenges in their alternative learning" (WM=2.87) Neutral, the least in rank is "Align better with student technology used which is reliable to digital devices in online learning process" (WM=2.79) Neutral. The overall $(\mathrm{AWM}=2.88)$ Neutral, which means access to digital work is moderately satisfied among the respondents.

Table 2: Implementation and readiness on availability of technology

\begin{tabular}{|l|c|c|c|}
\hline Indicators & WM & Interpretation & Ranking \\
\hline $\begin{array}{l}\text { 1. Availability of technology suffices the need of students in } \\
\text { their online classes which increase substantially their } \\
\text { knowledge in online learning process. }\end{array}$ & 2.63 & $\mathrm{~N}$ & 5 \\
\hline $\begin{array}{l}\text { 2. } \\
\text { Mobile devices, computers, and other applications can } \\
\text { support and help prepare student in their online learning } \\
\text { process. }\end{array}$ & 2.89 & $\mathrm{~N}$ & 3.5 \\
\hline
\end{tabular}




\begin{tabular}{|c|c|c|c|c|}
\hline & $\begin{array}{l}\text { Availability of technology in school classroom and home } \\
\text { is an effective way to connect student in their learning } \\
\text { process. }\end{array}$ & 2.89 & $\mathrm{~N}$ & 3.5 \\
\hline 4. & $\begin{array}{l}\text { Availability of technology provides student an } \\
\text { opportunity to enhance interaction with their classmates } \\
\text { and teachers by encouraging collaboration in their online } \\
\text { classes. }\end{array}$ & 2.97 & $\mathrm{~N}$ & 2 \\
\hline 5. & $\begin{array}{l}\text { Availability of technology transforms student } \\
\text { responsibility and learning experiences to new } \\
\text { opportunity of learning and empowers student on } \\
\text { technology to be more creative and connected in their } \\
\text { online learning classes and activities. }\end{array}$ & 3.05 & $\mathrm{~N}$ & 1 \\
\hline \multicolumn{2}{|r|}{ Average Weighted Mean } & 2.89 & $\mathrm{~N}$ & \\
\hline \multicolumn{2}{|c|}{ Standard Deviation } & 0.056 & & \\
\hline
\end{tabular}

Table 2 presents the weighted mean and the corresponding interpretation on availability of technology among students. It is observed that rank 1 is "Availability of technology transforms student responsibility and learning experiences to new opportunity of learning and empowers student on technology to be more creative and connected in their online learning classes and activities" (WM=3.05) Neutral, rank 2 is "Availability of technology provides student an opportunity to enhance interaction with their classmates and teachers by encouraging collaboration in their online classes" (WM=2.97) Neutral, rank 3 is shared by the two indicators which are "Mobile devices, computers, and other applications can support and help prepare students in their online learning process" and "Availability of technology in school classroom and home is an effective way to connect student in their learning process" (WM=2.89) Neutral, the least in rank is "Availability of technology suffices the need of student in their online classes which increase substantially their knowledge in online learning process" (WM=2.63) Neutral, and the overall (AWM=2.89) Neutral, which means availability of technology is moderately satisfied among students.

Table 3: Implementation and readiness on adequacy of technology

\begin{tabular}{|c|c|c|c|}
\hline Indicators & WM & Interpretation & Ranking \\
\hline $\begin{array}{l}\text { 1. It is flexible in online learning that provides student to } \\
\text { set their own learning pace and flexibility schedule that } \\
\text { fits their time to allow better learning. }\end{array}$ & 2.91 & $\mathrm{~N}$ & 4 \\
\hline $\begin{array}{l}\text { 2. It allows a wide and offers selection of program as to } \\
\text { internet, infinite skills subjects to teach student online } \\
\text { with various level and discipline. }\end{array}$ & 2.93 & $\mathrm{~N}$ & 3 \\
\hline $\begin{array}{l}\text { 3. It is accessible to online learning process that enables to } \\
\text { study or teach anywhere and anytime through internet } \\
\text { connection as an advantage for students. }\end{array}$ & 3.00 & $\mathrm{~N}$ & 1.5 \\
\hline $\begin{array}{l}\text { 4. It allows for a customise learning experience to help } \\
\text { student in their flexibility to study at their level and } \\
\text { ability to improve learning dynamic. }\end{array}$ & 3.00 & $\mathrm{~N}$ & 1.5 \\
\hline
\end{tabular}


A TRANSITION TO COVID 19 PANDEMIC

\begin{tabular}{|l|c|c|c|}
\hline \hline $\begin{array}{l}\text { 5. It is cost effective than traditional learning and tends to } \\
\text { be more affordable for better management allowance in } \\
\text { their studies. }\end{array}$ & 2.63 & $\mathrm{~N}$ & 5 \\
\hline Average Weighted Mean & 2.89 & $\mathrm{~N}$ & \\
\hline Standard Deviation & 0.056 & & \\
\hline
\end{tabular}

Table 3 presents the weighted mean and the corresponding interpretation on adequacy of technology among students. It is noted that rank 1 is shared by the two indicators which are "It is accessible to online learning process that enables to study or teach anywhere and anytime through internet connection as an advantage for students" and "It allows for a customise learning experience to help student in their flexibility to study at their level and ability to improve learning dynamic" (WM=3.00) Neutral, rank 2 is "It allows a wide and offers selection of program as to internet, infinite skills subjects to teach student online with various level and discipline" (WM=2.93) Neutral, rank 3 is "It is flexible in online learning that provides student to set their own learning pace and flexibility schedule that fits their time to allow better learning", (WM=2.91) Neutral, the least in rank is "It is cost effective than traditional learning and tends to be more affordable for better management allowance in their studies" (WM=2.63) Neutral, and the overall (AWM=2.89) Neutral, which means adequacy of technology is moderately satisfied among students.

Table 4: Implementation and readiness on access to effective online learning platform

\begin{tabular}{|c|c|c|c|}
\hline Indicators & WM & Interpretation & Ranking \\
\hline $\begin{array}{l}\text { 1. It is a teaching-learning platform online that enable } \\
\text { student to participate in their modular courses through } \\
\text { internet. }\end{array}$ & 3.01 & $\mathrm{~N}$ & 4.5 \\
\hline $\begin{array}{l}\text { 2. It enhances professional skills in online learning and } \\
\text { teaching through skills, attitude, and knowledge in a } \\
\text { competitive world of e-learning tailored with the global } \\
\text { demand of education due to Covid } 19 \text { pandemic. }\end{array}$ & 3.23 & $\mathrm{~N}$ & 1 \\
\hline $\begin{array}{l}\text { 3. It provides diverse mean of communicating flexibility } \\
\text { teaching online that enable to make learning possible that } \\
\text { simplifies the teaching process. }\end{array}$ & 3.15 & $\mathrm{~N}$ & 2 \\
\hline $\begin{array}{l}\text { 4. It customises the learning experience in online teaching } \\
\text { environment and assists student to focus on academic } \\
\text { objective for their learning process. }\end{array}$ & 3.09 & $\mathrm{~N}$ & 3 \\
\hline $\begin{array}{l}\text { 5. It requires active involvement and participates in virtual } \\
\text { study session in an optimum classroom design on the } \\
\text { level of engagement and ability of student support and } \\
\text { process. }\end{array}$ & 3.01 & $\mathrm{~N}$ & 4.5 \\
\hline Average Weighted Mean & 3.09 & $\mathrm{~N}$ & \\
\hline Standard Deviation & 0.063 & & \\
\hline
\end{tabular}

Table 4 presents the weighted mean and the corresponding interpretation on the access to effective online learning platform among the respondents. It is observed that rank 1 is "It enhances professional skills in online learning and teaching through skills, attitude, 
and knowledge in a competitive world of e-learning tailored with the global demand of education due to Covid 19 pandemic" (WM=3.23) Neutral, rank 2 is "It provides diverse mean of communicating flexibility teaching online that enable to make learning possible that simplifies the teaching process" (WM=3.15) Neutral, rank 3 is "It customises the learning experience in online teaching environment and assists student to focus on academic objectives for their learning process" (WM=3.09) Neutral, the least in rank is shared by the two indicators which are "It is a teaching-learning platform online that enable student to participate in their modular courses through internet" and "It requires active involvement and participates in virtual study session in an optimum classroom design on the level of engagement and ability of student support and process" (WM=3.01) Neutral, and the overall (AWM=3.09) Neutral, which means access to effective online learning platform among the lecturers is moderately satisfied.

Table 5: Implementation and readiness on access to link of internet

\begin{tabular}{|c|c|c|c|}
\hline Indicators & WM & Interpretation & Ranking \\
\hline $\begin{array}{l}\text { 1. It establishes a link to access for online learning process } \\
\text { as remedy to education of student during Covid } 19 \\
\text { pandemic and for other academic purposes. }\end{array}$ & 3.06 & $\mathrm{~N}$ & 4 \\
\hline $\begin{array}{l}\text { 2. It expands the link for provision to formal education in } \\
\text { online learning process utilisation and optimise the } \\
\text { existing education facilities and resources. }\end{array}$ & 3.08 & $\mathrm{~N}$ & 2.5 \\
\hline $\begin{array}{l}\text { 3. It provides access to internet that uses for online teaching } \\
\text { to communicate, manage, create, gather, access, and } \\
\text { distribute information for student learning. }\end{array}$ & 3.09 & $\mathrm{~N}$ & 1 \\
\hline $\begin{array}{l}\text { 4. It supports appropriately the teaching and learning of } \\
\text { student that can be effective to online teaching, improve } \\
\text { the quality and pedagogy content of knowledge toward } \\
\text { learning and teaching process. }\end{array}$ & 3.08 & $\mathrm{~N}$ & 2.5 \\
\hline $\begin{array}{l}\text { 5. It indicates the availability and importance of access to } \\
\text { internet integration and resources in teaching through } \\
\text { online adequacy necessary for education. }\end{array}$ & 3.03 & $\mathrm{~N}$ & 5 \\
\hline Average Weighted Mean & 3.07 & $\mathrm{~N}$ & \\
\hline Standard Deviation & 0.062 & & \\
\hline
\end{tabular}

Table 5 presents the weighted mean and the corresponding interpretation on access to link of internet among the respondents. As shown in the table rank 1 is "It provides access to internet that uses for online teaching to communicate, manage, create, gather, access, and distribute information for student learning" (WM=3.09) Neutral, rank 2 is shared by the two indicators which are "It expands the link for provision to formal education in online learning process utilisation and optimise the existing education facilities and resources" and "It supports appropriately the teaching and learning of student that can be effective to online teaching, improve the quality and pedagogy content of knowledge toward learning and teaching process" (3.08) Neutral, rank 3 is "It establishes a link to access for online learning process as remedy to education of student during Covid 19 pandemic and for other academic purposes" (MW=3.06) Neutral, the least in rank is "It 
indicates the availability and importance of access to internet integration and resources in teaching through online adequacy necessary for education" (WM=3.03) Neutral, and the overall (AWM=3.07) Neutral, which means access to link of internet among the lecturers is moderately satisfied.

Table 6: Implementation and readiness on school practices to online teaching

\begin{tabular}{|c|c|c|c|}
\hline Indicators & WM & Interpretation & Ranking \\
\hline $\begin{array}{l}\text { 1. School practices in online teaching are fascinating and } \\
\text { designs properly for course online and for positive } \\
\text { classroom setting. }\end{array}$ & 3.03 & $\mathrm{~N}$ & 5 \\
\hline $\begin{array}{l}\text { 2. Model of communication is transparent that can give } \\
\text { response to inquiry of student on their online content } \\
\text { learning process. }\end{array}$ & 3.09 & $\mathrm{~N}$ & 3.5 \\
\hline $\begin{array}{l}\text { 3. School is open to adjustment and constructive feedback } \\
\text { in a novice teaching online and innovation to technology } \\
\text { that will be helpful for student learning. }\end{array}$ & 3.25 & $\mathrm{~N}$ & 1 \\
\hline $\begin{array}{l}\text { 4. School designs a well-structured and flexible timelines in } \\
\text { online teaching to address problems on technical issues } \\
\text { encountered during the teaching process. }\end{array}$ & 3.09 & $\mathrm{~N}$ & 3.5 \\
\hline $\begin{array}{l}\text { 5. School provides link to website that is easily accessible } \\
\text { for instruction during online learning process as support } \\
\text { to student requiring complex navigation in the } \\
\text { applicability of classroom setting. }\end{array}$ & 3.22 & $\mathrm{~N}$ & 2 \\
\hline Average Weighted Mean & 3.13 & $\mathrm{~N}$ & \\
\hline Standard Deviation & 0.065 & & \\
\hline
\end{tabular}

Table 6 presents the weighted mean and the corresponding interpretation on school practices to online teaching among the respondents. It shows that rank 1 is "School is open to adjustment and constructive feedback in a novice teaching online and innovation to technology that will be helpful for student learning" (WM=3.25) Neutral, rank 2 is "School provides link to website that is easily accessible for instruction during online learning process as support to student requiring complex navigation in the applicability of classroom setting" (WM=3.22) Neutral, rank 3 is shared by the two indicators which are "Model of communication is transparent that can give response to inquiry of student on their online content learning process" and "School designs a well-structured and flexible timelines in online teaching to address problems on technical issues encountered during the teaching process" (WM=3.09) Neutral, the least in rank is "School practices in online teaching are fascinating and designs properly for course online and for positive classroom setting" (WM=3.03) Neutral, and the overall (AWM=3.13) Neutral, which means that school practices to online teaching is moderately satisfied among the teachers.

Table 7 shows the relationship between students and teachers in the transition of Covid 19 pandemic in the implementation and readiness of online learning. It reveals that when two variables are tested against each other, it shows that the critical $r$ values from the different categories are lower than the $r$ value of 0.159273 which means the relationship is not significant and the hypothesis is accepted. Therefore, it is safe to say 
that there is no significant relationship between students and teachers in the transition of Covid 19 pandemic in the implementation and readiness of online learning among the respondents and the alternative hypothesis is rejected.

Table 7: Significant relationship between students and teachers in the transition of the implementation and readiness of online learning

\begin{tabular}{|c|c|c|c|}
\hline Variable & $\begin{array}{c}\text { Computed } \\
\text { r-value }\end{array}$ & $\begin{array}{c}\text { Relationships } \\
\text { *significant } \\
\text { * not significant }\end{array}$ & $\begin{array}{c}\text { Hypotheses } \\
\text { *accepted } \\
\text { *rejected }\end{array}$ \\
\hline $\begin{array}{l}\text { A. Access to digital work } \\
\text { 1. Access to effective learning } \\
\text { 2. Link of internet } \\
\text { 3. School practices }\end{array}$ & $\begin{array}{l}0.027401 \\
0.027481 \\
0.027225 \\
\end{array}$ & $\begin{array}{l}\text { not significant } \\
\text { not significant } \\
\text { not significant }\end{array}$ & $\begin{array}{l}\text { accepted } \\
\text { accepted } \\
\text { accepted }\end{array}$ \\
\hline $\begin{array}{l}\text { B. Availability of technology } \\
\text { 1. Access to effective learning } \\
\text { 2. Link of internet } \\
\text { 3. School practices }\end{array}$ & $\begin{array}{l}0.027354 \\
0.027443 \\
0.027178 \\
\end{array}$ & $\begin{array}{l}\text { not significant } \\
\text { not significant } \\
\text { not significant }\end{array}$ & $\begin{array}{l}\text { accepted } \\
\text { accepted } \\
\text { accepted }\end{array}$ \\
\hline $\begin{array}{l}\text { C. Adequacy of technology } \\
\text { 1. Access to effective learning } \\
\text { 2. Link of internet } \\
\text { 3. School practices }\end{array}$ & $\begin{array}{l}0.027354 \\
0.027443 \\
0.027178\end{array}$ & $\begin{array}{l}\text { not significant } \\
\text { not significant } \\
\text { not significant }\end{array}$ & $\begin{array}{l}\text { accepted } \\
\text { accepted } \\
\text { accepted }\end{array}$ \\
\hline
\end{tabular}

Significant at 0.05 level, one-tailed test, df at 150 with critical r-value of 0.159273

\section{Discussion}

The flexible demand of online learning process and pedagogy offers a continues increase to address the challenges face during the Covid 19 pandemic as transition to educational system in terms of skills, training, and undertaking.

Nevertheless, on the transition of Covid 19 pandemic in the implementation and readiness of online learning through access of student to digital work reveals various pedagogies of tools in learning, materials, courses, and resources to improve the online process of learning. Online learning tools and resources improve the context of learning experience of student. It establishes an effort and interaction which is authentic to digital resource of learning and innovation (Aljawarneh, 2020). In addition, there is a course preparation to optimize planning lesson, giving mark to student on their performance effort, and understanding of individual need engagement and learning, there is an access to level of student insight and learning need in the different educational institutions which rely on analysis of the program to be implemented, data of time, and dashboard to equip lecturers for thorough analysis and understanding the student need, access that provides student to online learning pedagogy in content and increase affordable challenge and discipline in the modality of alternative learning, and better align the tool used for student reliable technology in the learning process digital device. It enhances the design pedagogy of online learning through skill and collaborative module and lesson for the promotion of literacy in technology (Blau, Shamir-Inbal \& Avdiel, 2020). 
Accordingly, on the transition to Covid 19 pandemic in the implementation and readiness of online learning pedagogy in terms of availability of technology reveals to transform student responsibility and learning experience to new opportunity of learning and empowers student on technology to be more creative and connected in their online learning classes and activities to provide practical learning in work and design for online learning process that contribute to their learning output considering the issues in online learning pedagogy (Fujita, 2020). Hence, it provides student the privilege and opportunity to interact with their classmates and teachers in collaboration of their online learning classes, it supplies different gadgets and devices and other applications that help and support student in the process of learning in school, classroom, and home sufficient to connect student in their learning pedagogy process, and it suffices the student need in their online learning classes. The pandemic provides adjustment to the educational institutions and options for the continued education and learning through the use of technology learning pedagogy and process. It implements and suggests initiative of online learning pedagogy and process during the pandemic crises (Demuyakor, 2020). It highlights the online learning desire of the different educational institutions and student access learning through technology in replacement of face to face teaching instruction (Adnan, \& Anwar, 2020).

Similarly, on adequacy of technology in the transition of Covid 19 pandemic in the implementation and readiness of online learning process pedagogy, it shows accessibility to online learning process and pedagogy for teaching and studying anytime and anywhere because of internet convenience advantage for the learners' experiences in their flexible learning level and ability to improve dynamic learning. This includes devices for learning, sites, and different apps for online learning and network. These tools are accessible in the different websites as a measure in online learning pedagogy of student (Pendergast, 2020). It also shows many selections of program that can be utilised in the online learning as to internet browser, skills in different discipline and level which is flexible that provide learning pace and schedule to allow learning time among student. It shows that online learning is cost effective as compared to traditional classroom learning affordable in the management of the allowance of student in their studies. Adequacy of technology among student is tangled because tools, devices, and programs evolved. There are many issues in technology like slow connection and availability. It reflects on the integration and support of technology in the learning setting of online process and pedagogy. There is a need to advocate student for adequate access to equal technology (Roth, 2020). It seeks to assess the adequacy of technology in online learning in advance system of education to enhance proper learning experience for lecturer and student motivation, expectancy, facilitation, and condition as a framework to online learning pedagogy (Gunasinghe, Abd Hamid, Khatibi, \& Azam, 2019).

Nonetheless, on the transition of implementation and readiness to access of effective online learning platform among respondents show that lecturers should enhance their skills in their profession through online in terms of attitude, knowledge and competency in the world of e-learning during Covid 19 pandemic. It provides a 
diverse mean of communication in flexible teaching that makes it possible for the learning and simplifies the process of teaching. It also customises the learning experience in online teaching environment and assists student to focus on academic objective for the learning process, and shows teaching-learning platform online to participate in their modular course through internet to include active involvement in virtual study session in an optimum classroom design on the level of engagement and ability of student support and process. It outlines and creates challenges in online learning process pedagogy which focuses on reflective activity among them, (Mpungose, 2020). On the other hand, the transition of online learning during Covid 19 pandemic aims to access online learning practice among respondents in the different educational institutions and addresses the worldwide online learning process and teaching need in providing the technical guidance for access to the usage of teaching and explore student in their learning process, (Utunen, et.al., 2020).

Consequently, on the access to link of internet among respondents show to provide online teaching internet access to manage, create, communicate, gather, and distribute information for student learning process. It shows also that link for provision is expanded for formal education in online learning process optimisation and utilisation on the existing educational resource, and facility. Teaching support can be effective to online learning process to improve the pedagogy and quality content of knowledge. It has also link and access online learning process as remedy to education during Covid 19 pandemic and for other academic purpose. It indicates the availability and importance of access to internet integration and resource in teaching through online necessary for education. Access to internet is the key to online learning especially the materials to be used like video, slides, assignment share, and message in the forum for the activity to be performed during the entire lesson. Motivation is needed for the different purposes, preferences, and behaviors. Students are interested to view the related materials for the lecture online. Access to link of internet is associated factor in the learning performance and motivation of student (Li, \& Tsai, 2017). On the other hand, online learning is needed for development and support in education that leads to process and content pedagogy among the learners. Flexibility can be performed when the access of internet is available in the process of learning anytime and anywhere. It is important to maintain the interaction on the learning impact from the different educational institutions in online learning implementation. Online learning emphasises to deal with the preparation in applying the steps on the benefits of the role of students and teachers in the limitation of online learning pedagogy (Verawardina, et al., 2020).

Certainly, on school practices to online teaching among respondents show that adjustment to school is open for constructive feedback in a novice teaching online and innovation to technology that will be helpful for student learning because they are the center of learning in the implementation of the educational system process. It also shows that school provides link website for utilisation during online learning process as support among student requiring complex navigation in the applicability of classroom setting. This is important to implement during the Covid 19 pandemic outbreak for the online 
learning process. It shows that communication model is transparent that can give response to inquiry of student in their online content learning process and school designs a well-structured and flexible timeline in online teaching to address problem on technical issue encountered during the teaching process. It shows that program for the online learning is designed prior for implementation. In addition, school practices in online teaching are fascinating and are designed properly for course online and for positive classroom setting. School develops the tool used for online learning pedagogy that can be built by teachers. It transforms the current practice and pedagogy to efficient online teaching. The transformation is structured and innovative in multi-level assessment and approach. It helps lecturer to transform, focus, and organise crucial learning experience (Itow, 2020). It is an approached to new learning in online pedagogy in the educational system. It describes the process and designs in online learning pedagogy transition from classroom setting to new online teaching setting perspective (Ferdig, Baumgartner, Hartshorne, Kaplan-Rakowski, \& Mouza, 2020). Thus, home quarantine, school disclosure, and social distancing are implemented among teachers. It is a practiced in the school online setting to include preventive measure and coping mechanism during Covid 19 pandemic. It is a requirement for virtual learning and teacher practice on the process of online learning pedagogy (Talidong, \& Toquero, 2020).

Since the study reveals that there is no significant relationship between students and teachers in the transition of Covid 19 pandemic in the implementation and readiness of online learning among the respondents. There must be continues study in the implementation and readiness of online learning on students' access to digital work, availability of technology, and adequacy of technology. Likewise, also to teachers' access to effective online learning platform, access to link of internet, and school practices to online teaching.

\section{Conclusion}

1. Access to digital work reveals e-learning to fit the different pedagogy of learning tools, resources, course materials to boost the impact of online learning process and pedagogy.

2. Availability of technology reveals to transform student responsibility and learning experience to new opportunity of learning and empowers student on technology to be more creative and connected in their online learning classes and activities.

3. Adequacy of technology reveals the accessibility of online learning process that enable to study or teach anywhere and anytime through internet connection as advantage for student and allows for a customise learning experience to help student in their flexibility to study at their level and ability to improve learning dynamic.

4. Access to effective online learning platform reveals to enhance professional skills in online learning and teaching through skill, attitude, and knowledge in a 
competitive world of e-learning tailored with the global demand of education due to Covid 19 pandemic.

5. Access to link of internet reveals to provide access tool and device used for online teaching to communicate, manage, create, gather, access, and distribute information for student learning.

6. School practices to online teaching reveals to open for adjustment and constructive feedback in a novice teaching online and innovation to technology that will be helpful for student learning.

\section{Recommendation}

1. Align better access to digital work with student technology usage reliable to digital devices in online learning process and pedagogy. This is significant in the learning process of student in the different educational institutions.

2. Availability of technology must suffice the need of student in their online classes which increase substantially their knowledge in online learning process like the different apps for advance learning.

3. Adequacy of technology must be cost effective than traditional learning and tends to be more affordable for better management allowance in student learning process. Consider the financial stability of the learners.

4. Access to effective online learning platform must enable student to participate in their modular course through internet and requires active involvement and participation in virtual study session in an optimum classroom design on the level of engagement ability support and process.

5. Access to link of internet must indicate the availability and importance of access integration and resource in teaching through online adequacy necessary for education. It is most needed and useful in online learning process pedagogy.

6. School practices in online teaching must be fascinating and designed properly for course online and for positive classroom setting since students have difficulty in the adjustment of online setting learning process.

7. Since there is no significant relationship between students and teachers in the transition of Covid 19 pandemic in the implementation and readiness of online learning among the respondents, future researches must be explored like motivation of student to participate in online learning process and pedagogy, benefits, and significance. This can help student to perform better in their online lessons.

\section{References}

1. Adnan, M., \& Anwar, K. (2020). Online Learning amid the COVID-19 Pandemic: Students' Perspectives. Online Submission, 2(1), 45-51. 
2. Aljawarneh, S. A. (2020). Reviewing and exploring innovative ubiquitous learning tools in higher education. Journal of computing in higher education, 32(1), 57-73.

3. Blau, I., Shamir-Inbal, T., \& Avdiel, O. (2020). How does the pedagogical design of a technology-enhanced collaborative academic course promote digital literacies, self-regulation, and perceived learning of students?. The internet and higher education, 45, 100722.

4. Chen, H., Qian, W., \& Wen, Q. (2020). The impact of the COVID-19 pandemic on consumption: Learning from high frequency transaction data. Available at SSRN 3568574.

5. Cutri, R. M., \& Mena, J. (2020). A critical reconceptualization of faculty readiness for online teaching. Distance Education, 41(3), 361-380.

6. Demuyakor, J. (2020). Coronavirus (COVID-19) and online learning in higher institutions of education: A survey of the perceptions of Ghanaian international students in China. Online Journal of Communication and Media Technologies, 10(3), e202018.

7. Febliza, A., \& Okatariani, O. (2020). The Development of Online Learning Media by Using Moodle for General Chemistry Subject. Journal of Educational Science and Technology (EST), 6(1), 40-47.

8. Ferdig, R. E., Baumgartner, E., Hartshorne, R., Kaplan-Rakowski, R., \& Mouza, C. (2020). Teaching, technology, and teacher education during the covid-19 pandemic: Stories from the field. Waynesville, NC, USA: Association for the Advancement of Computing in Education (AACE).

9. Fujita, N. (2020). Transforming online teaching and learning: towards learning design informed by information science and learning sciences. Information and Learning Sciences.

10. Gunasinghe, A., Abd Hamid, J., Khatibi, A., \& Azam, S. F. (2019). The adequacy of UTAUT-3 in interpreting academician's adoption to e-Learning in higher education environments. Interactive Technology and Smart Education.

11. Henriksen, D., Creely, E., \& Henderson, M. (2020). Folk Pedagogies for Teacher Transitions: Approaches to Synchronous Online Learning in the Wake of COVID19. Journal of Technology and Teacher Education, 28(2), 201-209.

12. Herodotou, C., Rienties, B., Boroowa, A., Zdrahal, Z., \& Hlosta, M. (2019). A largescale implementation of predictive learning analytics in higher education: the teachers' role and perspective. Educational Technology Research and Development, 67(5), 1273-1306.

13. Itow, R. C. (2020). Fostering valuable learning experiences by transforming current teaching practices: practical pedagogical approaches from online practitioners. Information and Learning Sciences.

14. Klar, S., \& Leeper, T. J. (2019). Identities and intersectionality: a case for Purposive sampling in Survey-Experimental research. Experimental Methods in Survey Research: Techniques that Combine Random Sampling with Random Assignment, 419-433. 
15. Li, L. Y., \& Tsai, C. C. (2017). Accessing online learning material: Quantitative behavior patterns and their effects on motivation and learning performance. Computers \& Education, 114, 286-297.

16. Malekian, D., Bailey, J., \& Kennedy, G. (2020, March). Prediction of students' assessment readiness in online learning environments: the sequence matters. In Proceedings of the Tenth International Conference on Learning Analytics $\mathcal{E}$ Knowledge (pp. 382-391).

17. Mallillin, Leovigildo Lito D. (2020). Different Domains in Learning and the Academic Performance of the Students. Journal of Educational System, 4(1), 1-11.

18. Mallillin, L. L. D., Carag, E. A., Mallillin, J. B., \& Laurel, R. D. (2020). Integration of knowledge through online classes in the learning enhancement of students. European Journal of Open Education and E-learning Studies.

19. Martin, F., Stamper, B., \& Flowers, C. (2020). Examining Student Perception of Readiness for Online Learning: Importance and Confidence. Online Learning, 24(2), 38-58.

20. Mpungose, C. B. (2020). Is Moodle or WhatsApp the preferred e-learning platform at a South African university? First-year students' experiences. Education and information technologies, 25(2), 927-941.

21. Pendergast, M. O. (2020). Evaluating the accessibility of online university education. In Accessibility and Diversity in Education: Breakthroughs in Research and Practice (pp. 19-33). IGI Global.

22. Powell, C. G., \& Bodur, Y. (2019). Teachers' perceptions of an online professional development experience: Implications for a design and implementation framework. Teaching and Teacher Education, 77, 19-30.

23. Putney, J. M., Levine, A. A., Collin, C. R., O’Brien, K. H., Mountain-Ray, S., \& Cadet, T. (2019). Teaching note-Implementation of online client simulation to train and assess screening and brief intervention skills. Journal of Social Work Education, 55(1), 194-201.

24. Reimers, F. M., \& Schleicher, A. (2020). A framework to guide an education response to the COVID-19 Pandemic of 2020. OECD. Retrieved April, 14, 2020.

25. Robinson, H. A., Al-Freih, M., \& Kilgore, W. (2020). Designing with care: Towards a care-centered model for online learning design. The International Journal of Information and Learning Technology, 37(3), 99-108.

26. Roth, K. (2020). Technology in Education: The Ongoing Debate of Access, Adequacy and Equity.

27. Santika, N. (2019). The Effect of Professionalism Competencies on the Teachers' Performance (Quantitative Descriptive Research of English Teachers at SMA N 3 North Bengkulu in Academic Year 2018/2019) (Doctoral dissertation, Iain Bengkulu).

28. Utunen, H., Ndiaye, N., Piroux, C., George, R., Attias, M., \& Gamhewage, G. (2020). Global Reach of an Online COVID-19 Course in Multiple Languages on 
Open WHO in the First Quarter of 2020: Analysis of Platform Use Data. Journal of Medical Internet Research, 22(4), e19076.

29. Verawardina, U., Asnur, L., Lubis, A. L., Hendriyani, Y., Ramadhani, D., Dewi, I. P., \& Sriwahyuni, T. (2020). Reviewing Online Learning Facing the Covid-19 Outbreak. Talent Development \& Excellence, 12. 
Leovgildo Lito D. Mallillin, Lorna Casoco Mendoza, Jocelyn B. Mallillin, Rosina C. Felix, Imelda C. Lipayon IMPLEMENTATION AND READINESS OF ONLINE LEARNING PEDAGOGY:

A TRANSITION TO COVID 19 PANDEMIC

Creative Commons licensing terms

Authors will retain the copyright of their published articles agreeing that a Creative Commons Attribution 4.0 International License (CC BY 4.0) terms will be applied to their work. Under the terms of this license, no permission is required from the author(s) or publisher for members of the community to copy, distribute, transmit or adapt the article content, providing a proper, prominent and unambiguous attribution to the authors in a manner that makes clear that the materials are being reused under permission of a Creative Commons License. Views, opinions and conclusions expressed in this research article are views, opinions and conclusions of the author(s). Open Access Publishing Group and European Journal of Open Education andE-learning Studies shall not be responsible or answerable for any loss, damage or liability caused in relation to/arising out of conflict of interests, copyright violations and inappropriate or inaccurate use of any kind content related or integrated on the research work. All the published works are meeting the Open Access Publishing requirements and can be freely accessed, shared, modified, distributed and used in educational, commercial and non-commercial purposes under a Creative Commons Attribution 4.0 International License (CC BY 4.0). 